\title{
Delirium After Chloralhydrate in A Child-A Case Report
}

\section{Çocukta Kloralhidrat Sonrası Deliryum - Olgu Sunumu}

\author{
İlknur Sürücü Kara1 ${ }^{1}$ İlke Küpeli²
}

1Ankara University Medical Faculty, Department of Child Metabolism, Ankara, Turkey

2Biruni University Faculty of Medicine, Department of Anesthesiology and Reanimation, Istanbul, Turkey

$\ddot{O} Z$

Kloralhidrat, çocuklarda sedasyonun yeterli olduğu ve analjezinin gerekli olmadı̆g görüntüleme yöntemleri için sedatif hipnotik ilaç olarak kullanılan bir ilaçtır. Geniş terapötik indeksi, nispeten düşük solunum depresyonu, uygulama kolaylığ ve daha az slklıkta yan etkileri nedeniyle yaygin olarak kullanilmaktadir. Deliryumun birçok yerde kloral hidratın yan etkisi olarak bahsedilmesine rağmen, hiçbir vaka raporu bulunmamaktadır. Bu olgu sunumunda kloralhidratın terapötik kullanımından sonra deliryum gelişen bir çocuğa değinilmiştir.

Anahtar Kelimeler: kloralhidrat, deliryum, çocuk

\section{ABSTRACT}

Chloralhydrate is a drug that is used as sedative - hypnotic drug for imaging methods where analgesia is not required and sedation is sufficient in children. It is widely used because of its wide therapeutic index, relatively low respiratory depression, ease of administration and less frequent side effects. Although delirium was mentioned as the side effect of chloral hydrate in many places, no case report could be detected. In this case report, a child who developed delirium after the therapeutic use of chloralhydrate was mentioned.

Keywords: chloralhydrate, delirium, pediatric

\section{İletisisim / Correspondence:}

Ilknur Sürücü Kara

Ankara University Medical Faculty, Department of Child Metabolism,

Ankara, Turkey

ilkeser2004@gmail.com

Başvuru Tarihi: 26.12.2020

Kabul Tarihi: 16.11.2021
Doi: 10.5505/ktd.2021.33349

Ilknur Sürücü Kara: 0000-0001-7842-9278

Ilke Küpeli: 0000-0003-3518-7365 


\section{INTRODUCTION}

It is difficult to achieve immobility in children in situations such as radiological imaging, tooth extraction, EEG, ECG, and suturing. In such cases, the use of chloralhydrate for sedation is still practiced in many centers. (1).

Chloralhydrate is a drug used as a sedative hypnotic drug in imaging methods that do not require analgesia and sedation is sufficient in children. It is widely used because of its broad therapeutic index, relatively low respiratory depression, ease of administration, and fewer side effects. The preferred dose is 25 to $50 \mathrm{mg} / \mathrm{kg}$ up to a maximum of 1 g.(2). Chloralhydrate, a commonly used sedative in children, has many serious side effects in high or toxic doses. Some of those; prolonged sedation, paradoxical excitement, delirium, and unpleasant taste sensations. (3).

Delirium is defined as a disturbance in attention, awareness, and cognition over a short period of time that is not explained by a pre-existing neurocognitive disorder, or a decreased level of arousal attributed to a medical condition, intoxication, withdrawal, or a medication side effect (4).

Although delirium is mentioned in many places as a side effect of chloral hydrate, no case report has been found. Our case is a child who developed delirium after administration of chloralhydrate.

\section{CASE REPORT}

Written consent has been obtained from the patient's relatives.

A. 5.5-year-old girl with a weight of $20 \mathrm{~kg}$ was admitted to the outpatient clinic due to occasional nonspecific headache. Brain magnetic resonance imaging of the patient was requested, but chloralhydrate $50 \mathrm{mg} / \mathrm{kg} / \mathrm{dose}$ was administered 2 times, one hour apart, for sedation so that he would not move during the procedure. Half an hour after the second dose, there was a slowing in her speech and movements, numbness in her hands and legs. Afterwards, she has acted in a manner that hurts herself and her surroundings, has been rebellious and she was brought to the emergency room of the pediatric emergency department with these complaints. The patient was not making eye contact with his mother. The child's actions weren't purposeful, she was unaware of her surroundings, restless and inconsolable. We measure/observe delirium with The Pediatric Anesthesia Emergence Delirium (PAED) scale in our clinic. Her PAED score was 18.

With the recommendation of the poison counselor, after the active charcoal was given, the patient was admitted to the service for 24-hour follow-up. All laboratory tests, systemic and neurological examinations were normal. She had agitation for 2-3 hours before and she had euphoric behaviors for 8-9 hours. During this period, vital signs were stable. She started to behave completely normal in about 12-13 hours. She discharged without problems.

\section{DISCUSSION}

In children, delirium is an altered state of consciousness, which occurs with anesthesia and continues until early recovery. Awareness or attention disorder about the child's environment and manifests itself as disorientation, hyperactive behavior and hypersensitivity in the acute period after anesthesia (5).

Since the late 1800 s, chloral hydrate, has been widely used in pediatric sedation, especially in newborns and infants for the last three decades. Also in our clinic, chloralhydrate is used routinely if necessary. Chloralhydrate can be administered orally or rectally and absorbed from the gastrointestinal tract with the highest serum concentrations within 30-60 minutes. In pediatric patients, the dose of chloralhydrate is 25 to $50 \mathrm{mg} /$ $\mathrm{kg}$ and up to 1 gram $(1,2)$. In vivo, it converts to trichloroethane, which is a sedative and active form. its half-life is about 8-12 hours, but its acute overdose and in intoxications half-life can be up to 35 hours. It is recommended not to be used in children older than 4 years or in children with neurodevelopmental disorders due to the increased risk of adverse effects and treatment failure (1).

From 1996 to 2009, the Institute for Safe Drug Administration (ISMP) stated that there were 8 deaths and a number of misuse related use of faulty chloralhydrate for pediatric sedation. In 2014, the institute reported that a 4-year-old girl could not be awakened from sleep for a long time after chloralhydrate from $70 \mathrm{mg} / \mathrm{kg}$ for dental treatment and was ex-home. In the report, it was state that a 3year-old child was given $6000 \mathrm{mg}$ chloralhydrate accidentally, after vomiting, respiratory arrest, 
intubated and monitored and again it was stated that $100 \mathrm{mg} / \mathrm{kg}$ dose was given to another patient for 15 months, stridor and apnea developed after vomiting, followed up for 12 hours and discharged (1).

Chloralhydrate is no longer recommended for sedation in children and is not available in many countries, including the United States. Some countries have removed chloralhydrate from national health formulas because of their potential carcinogenicity (6).

Due to the delayed initial action of chloralhydrate, long duration of action and the high frequency of side effects, given the availability of better alternatives, the use of chloralhydrate is no longer recommended $(7,8)$. Italy and France were also banned in 2016, in the United States in 2012 due to carcinogenicity and genotoxicity (9).

There are studies suggesting that preoperative anxiety decreases with oral chloral hydrate and has little effect on postoperative delirium and postoperative maladaptive behavior (2). In some studies, $4 \%$ to $7 \%$ of participants were reported that other adverse effects such as sedation failures (20\%), prolonged sedation (19\%), excessive drowsiness, airway obstruction, respiratory depression, hypercapnia, post-discharge sedation, respiratory arrest, hypotension and cardiopulmonary arrest (1). The risk of resedation that lasts longer than 24 hours may occur at any age in children, even in therapeutic doses (10).

In Uptodate and the drug package insert, it is indicated that it has some side effects even when taken in appropriate doses. These; In cardiovascular system: Atrial arrhythmia, depression of myocardial contractility, hypotension, torsades de pointes, shortening of refractory periods, ventricular arrhythmia. In the central nervous system: Abnormal gait, ataxia, confusion, delirium, dizziness, drowsiness, drug addiction (if used for a long time), hallucinations, hangover effect, weakness, nightmares, paradoxical excitation, vertigo. Dermatologic: Skin rash. Endocrine and metabolic: Acute porphyria, ketonuria. In the gastrointestinal tract: diarrhea, gas, stomach irritation, nausea, vomiting. Hematological and oncologic: acute porphyria, eosinophilia, leukopenia. In the eyes: Allergic conjunctivitis, blepharoptosis, keratoconjunctivitis. In Ear: Increased middle ear pressure (infants and children). In the respiratory system: Airway obstruction (young children), laryngeal edema (children). Potential cardiotoxic effects such as ventricular dysrhythmias and hypotension may occur at high or overdose. Unfortunately, there is no known antidote of chloral hydrate (1).

Delirium in children is usually for a short time after recovery from anesthesia (5), but our patient developed delirium after chloral hydrate without any sedation.

In our patient, delirium developed after $100 \mathrm{mg} /$ $\mathrm{kg}$ chloralhydrate, activated charcoal was given and hydration was provided. There were no abnormalities in blood values and vital signs during follow-up.

\section{CONCLUSION}

Chloralhydrate is prohibited in many countries. In many countries, it is one of the most frequently used sedative drugs that are used as controlled. However, due to the long duration of the effects, the lack of controlled follow-up, and the serious side effects leading to death, even if given in the appropriate dose, the unit with intensive care conditions should be given under clinical supervision and then followed up.

Ethics Committee Approval: This is a case report.

Conflict of Interest: There is no conflict of interest.

Funding: There is no financial support.

Informed Consent: Patient consent was obtained.

\section{REFERENCES}

1. Paparella SF. Chloral Hydrate: Safety Risks Still Worth Mentioning. Journal of Emergency Nursing. 2018;44(1):81-3.

2. Kil HK, Kim WO, Han SW, Kwon Y, Lee A, Hong JY. Psychological and behavioral effects of chloral hydrate in day-case pediatric surgery: a randomized, observer-blinded study. Journal of pediatric surgery. 2012;47(8):1592-9.

3.Zhang W, Wang Z, Song X, Fan Y, Tian H, Li B. Comparison of rescue techniques for failed chloral 
hydrate sedation for magnetic resonance imaging scans--additional chloral hydrate vs intranasal dexmedetomidine. Paediatr Anaesth. 2016;26(3):273-9.

4.Cunningham ME, Vogel AM, editors. Analgesia, Sedation, and Delirium in Pediatric Surgical Critical Care. Seminars in Pediatric Surgery; 2019: Elsevier.

5.Malarbi S, Stargatt R, Howard K, Davidson A. Characterizing the behavior of children emerging with delirium from general anesthesia. Pediatric Anesthesia. 2011;21(9):942-50.

6.Sahyoun C, Krauss B. Clinical implications of pharmacokinetics and pharmacodynamics of procedural sedation agents in children. Current opinion in pediatrics. 2012;24(2):225-32.

7.Litman RS, Soin K, Salam A. Chloral hydrate sedation in term and preterm infants: an analysis of efficacy and complications. Anesth Analg. 2010;110(3):739-46.

8.Macias CG, Chumpitazi CE. Sedation and anesthesia for CT: emerging issues for providing high-quality care. Pediatric radiology. 2011;41 Suppl 2:517-22.

9.Cozzi G, Norbedo S, Barbi E. Intranasal Dexmedetomidine for Procedural Sedation in Children, a Suitable Alternative to Chloral Hydrate. Paediatric drugs. 2017;19(2):107-11.

10.Malviya S, Voepel-Lewis T, Prochaska G, Tait AR. Prolonged recovery and delayed side effects of sedation for diagnostic imaging studies in children. Pediatrics. 2000;105(3):E42. 